\title{
Two Species of Paracalliopiidae from the Ryukyu Archipelago in Japan, with the Description of a New Species (Crustacea: Amphipoda)
}

\author{
Hiroyuki Ariyama \\ Osaka Museum of Natural History, Nagai Park, Higashi-Sumiyoshi, Osaka 546-0034, Japan \\ E-mail: Ariyamah@rinku.zaq.ne.jp \\ (Received 27 October 2020; Accepted 31 January 2021)
}

http://zoobank.org/5B86B101-40CC-4349-A39C-BC4B55CDE282

\begin{abstract}
Two species of the paracalliopiid Amphipoda are recorded from the Ryukyu Archipelago in Japan, one of which is Mucrocalliope ryukyuensis sp. nov., the second species of the genus. This new species is very similar to the type species, $M$. shimantoensis Ariyama and Azuma, 2011 from the Shimanto estuary, western Japan; however, M. ryukyuensis can be distinguished from $M$. shimantoensis by the longer peduncular article 4 of the male antenna 2 and the basis of the male pereopod 5 with a posteromedial plumose seta. The other species is Paracalliope dichotomus Morino, 1991; its morphology in female and the coloration are firstly described.
\end{abstract}

Key Words: Mucrocalliope, Paracalliope, morphology, coloration, Kakeroma Island, Okinawa Island, Iriomote Island, coxal gill.

\section{Introduction}

The amphipod family Paracalliopiidae is a small group containing only 19 species in six genera and is characterized by the coalesced urosomites 2 and 3 and the elongate pereopod 7 (Ariyama and Azuma 2011). In Japan, two species of the family have been recorded: Paracalliope dichotomus Morino, 1991 from Okinawa Island and Mucrocalliope shimantoensis Ariyama and Azuma, 2011 from Shimanto estuary in Kochi Prefecture.

During my survey of the amphipod fauna in the Ryukyu Archipelago (see Ariyama 2020), two species included in the family were obtained and closer examination has revealed that one of them is new to science. In the present paper, the morphology and coloration of the two species are described.

\section{Materials and Methods}

Examined specimens were collected in the intertidal zone and the uppermost subtidal zone in the Ryukyu Archipelago with a hand net or decantation method (cf. Ariyama 2016). Collecting sites of the examined specimens are shown in Fig. 1. All the specimens were dissected and appendages of a part of the specimens were drawn using a phase-contrast microscope with an attached drawing tube. Body length (BL) was measured from the apex of the rostrum along the dorsal margin to the distal end of the urosomite 3. The material examined, including type specimens, is deposited in the Osaka Museum of Natural History, Japan (OMNH).

\section{Taxonomic Account}

Family Paracalliopiidae Barnard and Karaman, 1982 [Japanese name: Genkotsu-yokoebi-ka] Genus Mucrocalliope Ariyama and Azuma, 2011 [Japanese name: Toge-genkotsu-yokoebi-zoku]

Mucrocalliope Ariyama and Azuma, 2011: 138.

Type species. Mucrocalliope shimantoensis Ariyama and Azuma, 2011, fixed by original designation.

Emended diagnosis. Body subcylindrical, posterior margins of pleonites 1 and 2 each with acute dorsal tooth, urosomites 2 and 3 coalesced. Rostrum short; eyes large in male, clearly separated; antennal sinus shallow. Antennae slender, male antennae with calceoli; antenna 1 peduncular article 3 shorter than article 1, accessory flagellum vestigial. Upper lip with long setae. Mandibular palp stout; incisor and molar developed. Maxilla 1 with inner plate bearing single plumose seta; outer plate with many apical robust setae; palp 2-articulated, with apical setae. Maxilla 2 with both plates bearing apical setae, inner plate lacking dense medial setae. Maxillipedal palp consisting of 4 articles, exceeding outer plate. Coxae strongly overlapping; coxae 1-4 longer than broad, 5-7 short, coxae 5 and 6 bilobed; gills present on coxae 2-6 in male and coxae 2-7 in female; oostegites of female present on coxae $2-5$, oostegites on coxae 2 and 3 large. Gnathopod 1 of both sexes small, subchelate; basis slender; carpus with posterodistal lobe; propodus longer than carpus, palm oblique. Male gnathopod 2 stout, subchelate; basis robust; carpus short, with narrow posterodistal 


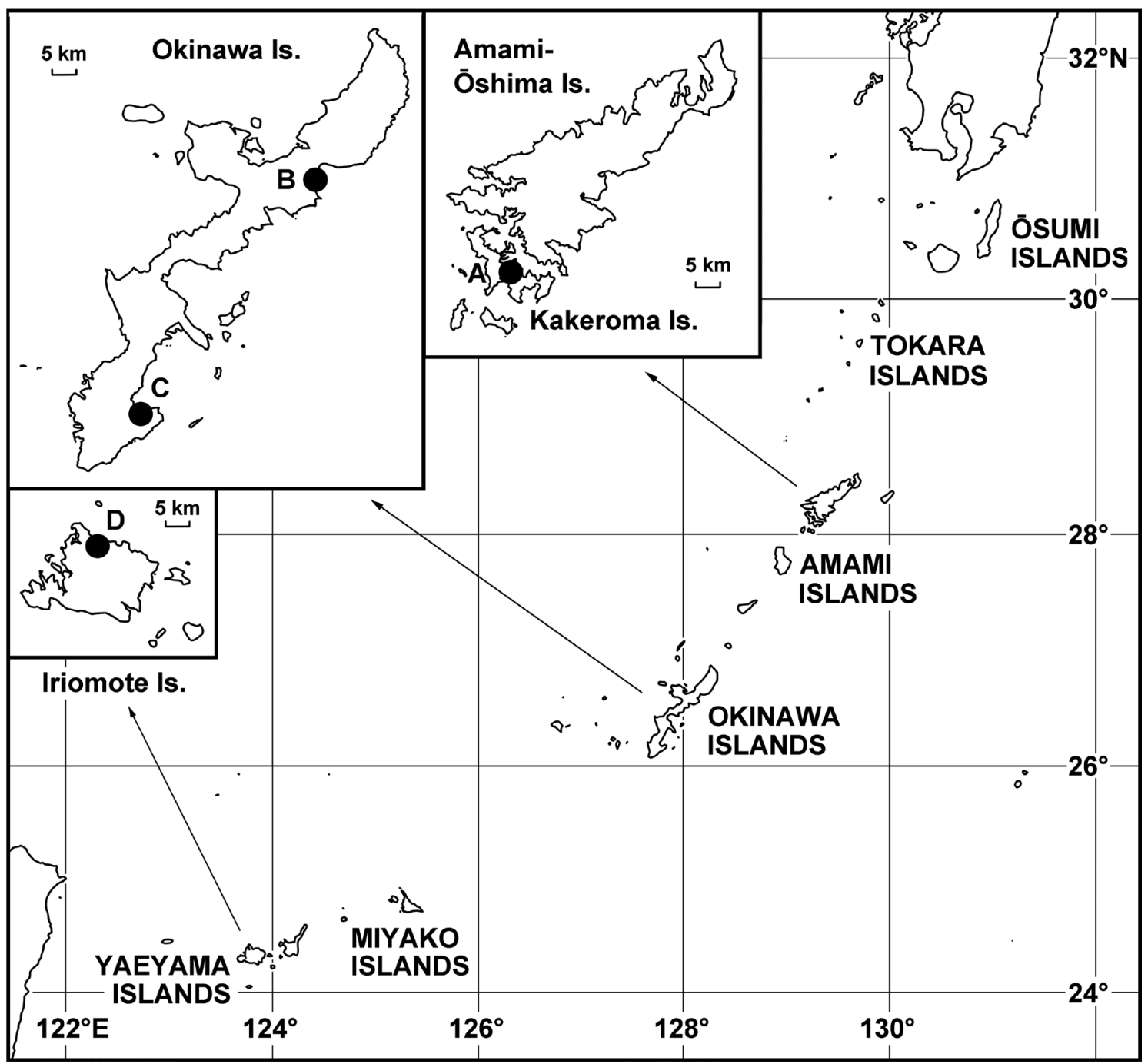

Fig. 1. Map showing collecting sites of examined specimens in the Ryukyu Archipelago.

lobe; propodus dilated, palm oblique, with several robust setae. Female gnathopod 2 small, subchelate; basis slender; carpus with posterodistal lobe; propodus longer than carpus, palm weakly oblique. Pereopods 3-6 not fossorial. Pereopods 3 and 4 similar; bases slender; dactyli curved. Pereopods 5 and 6 each with expanded basis and curved dactylus. Pereopod 7 extremely long; basis expanded; dactylus elongate, tapering distally. Pleonal epimera each with posteroventral tooth. Uropods biramous, slender; inner rami longer than outer rami. Telson entire, longer than broad.

Included species. Two species: Mucrocalliope ryukyuensis sp. nov.; M. shimantoensis.

Remarks. As new information was revealed through the present study, diagnosis of the genus (Ariyama and Azuma 2011) is emended herein. Sexual dimorphism in gill arrangement (on coxae 2-6 in male, on coxae 2-7 in female) is newly introduced in this diagnosis. The presence of the pereopod 7 gill is rare among marine gammaridean amphipods (Steel and Steel 1991; Ariyama and Moritaki 2020) and the presence only in female has not been recorded.
Mucrocalliope ryukyuensis sp. nov.

[New Japanese name: Ryūkyū-toge-genkotsu-yokoebi]

(Figs 2-9)

Material examined. Holotype: male (OMNH-Ar-12077), $2.8 \mathrm{~mm}$, mouth of Gesashi River, Higashi Village, Okinawa Island, Okinawa Prefecture (Fig. 1B), 26 $36^{\prime} 17^{\prime \prime} \mathrm{N}$, $128^{\circ} 08^{\prime} 38^{\prime \prime} \mathrm{E}$, middle intertidal, sandy mud bottom with mangrove leaves, 2 July 2015, coll. H. Ariyama. Paratypes: 3 males (OMNH-Ar-12179, 12078, 12079), 2.5, 2.5 and $2.4 \mathrm{~mm}$, respectively, and 1 ovigerous female (OMNHAr-12080), $2.3 \mathrm{~mm}$, same locality, $26^{\circ} 36^{\prime} 15^{\prime \prime} \mathrm{N}, 128^{\circ} 08^{\prime} 39^{\prime \prime} \mathrm{E}$, middle intertidal, sandy mud bottom, 2 July 2015, coll. $\mathrm{H}$. Ariyama; 1 ovigerous female (OMNH-Ar-12081), $2.3 \mathrm{~mm}$, same locality, $26^{\circ} 36^{\prime} 05^{\prime \prime} \mathrm{N}, 128^{\circ} 08^{\prime} 30^{\prime \prime} \mathrm{E}$, lower intertidal, fine sand bottom, 2 July 2015, coll. H. Ariyama; 1 ovigerous female (OMNH-Ar-12082), $2.3 \mathrm{~mm}$, same locality, $26^{\circ} 36^{\prime} 16^{\prime \prime} \mathrm{N}, 128^{\circ} 08^{\prime} 38^{\prime \prime} \mathrm{E}$, middle intertidal, sandy bottom with gravel, 2 July 2015, coll. H. Ariyama; 1 male (OMNHAr-12083), $2.1 \mathrm{~mm}$, mouth of Māre River, Funaura, Iriomote Island, Okinawa Prefecture, $24^{\circ} 23^{\prime} 28^{\prime \prime} \mathrm{N}, 123^{\circ} 49^{\prime} 02^{\prime \prime} \mathrm{E}$ (Fig. 1D), uppermost subtidal, mud bottom, 18 July 2015, coll. H. 


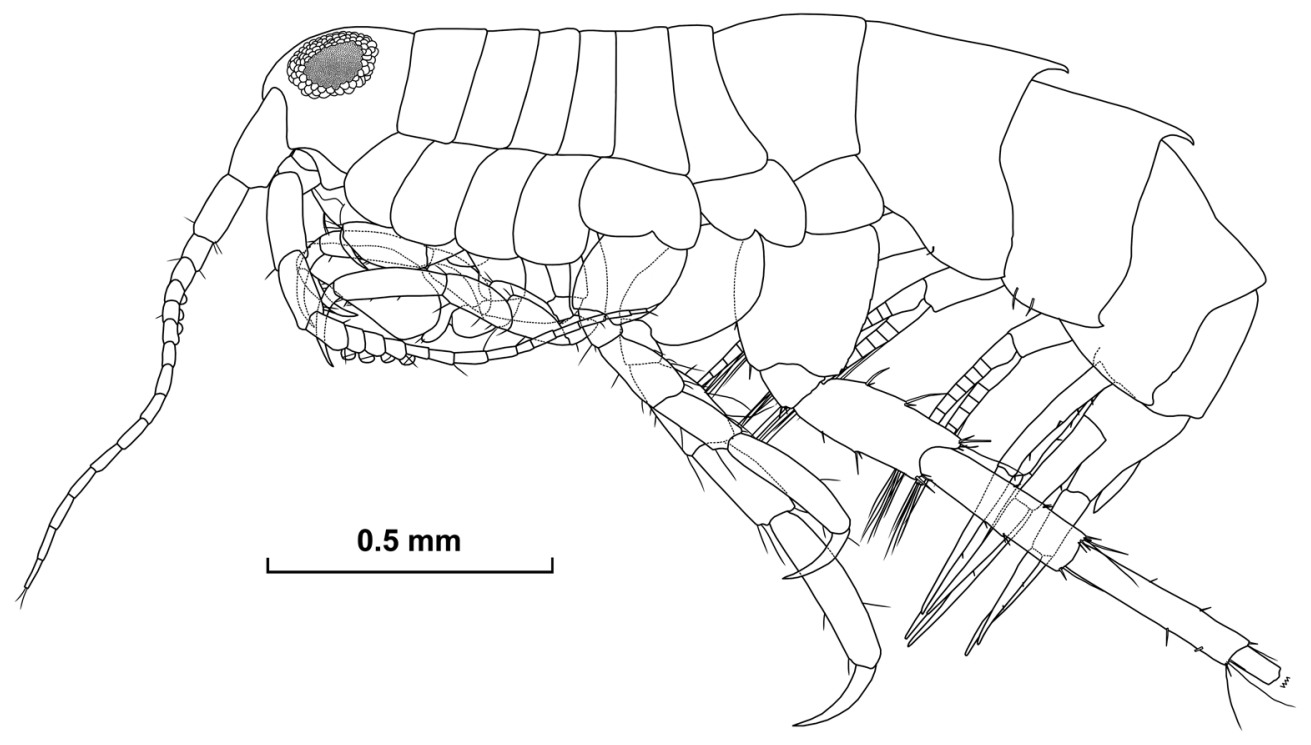

Fig. 2. Mucrocalliope ryukyuensis sp. nov., paratype, male (OMNH-Ar-12179), $2.5 \mathrm{~mm}$, habitus, left lateral view.

Ariyama; 1 ovigerous female (OMNH-Ar-12084), $2.2 \mathrm{~mm}$, Nominoura, Kakeroma Island, Kagoshima Prefecture, $28^{\circ} 07^{\prime} 01^{\prime \prime} \mathrm{N}, 129^{\circ} 15^{\prime} 36^{\prime \prime} \mathrm{E}$ (Fig. 1A), upper intertidal, sandy mud bottom with gravel, 4 July 2019, coll. H. Ariyama.

Material for comparison. Mucrocalliope shimantoensis. Holotype: male (OMNH-Ar-8689), $2.2 \mathrm{~mm}$, Shimanto estuary, Kochi Prefecture, $32^{\circ} 56^{\prime} 31^{\prime \prime} \mathrm{N}, 132^{\circ} 58^{\prime} 32^{\prime \prime} \mathrm{E}$, uppermost subtidal, mud bottom with seagrass, 14 May 2007, coll. K. Azuma and H. Hiraga. Paratypes: 2 males (OMNHAr-8690, 8691), 2.4 and $2.3 \mathrm{~mm}$, respectively, and 2 females (OMNH-Ar-8692, 8693), 2.8 and $2.1 \mathrm{~mm}$, respectively, same data as holotype.

Type locality. Mouth of Gesashi River, Higashi Village, Okinawa Island, Okinawa Prefecture.

Etymology. Referring to the collecting sites of the species.

Description of male. Based on holotype (OMNHAr-12077, $2.8 \mathrm{~mm}$ ), paratype (OMNH-Ar-12179, $2.5 \mathrm{~mm}$ ) only for habitus and paratype (OMNH-Ar-12078, $2.5 \mathrm{~mm}$ ) for maxilla 1 and pereopod 5 .

Body (Fig. 2) relatively slender; pereonites 1-6 narrow, pereonite 7 and pleonites $1-3$ wide, pleonites 1 and 2 each with distinct posterodorsal tooth.

Head. Eyes (Fig. 2) large (diameter: $6.4 \%$ of BL). Antenna 1 (Fig. 3A, A1), peduncular articles $1-3$ with length ratio of 1.0:0.65:0.4, article 1 stout; accessory flagellum 1-articulate, with 2 setae on tip; flagellum with 13 articles, last article minute, articles 1 and 2 in right and articles 1-3 in left each with calceolus medially, articles 9-12 each bearing aesthetasc at distal end. Antenna 2 (Fig. 3B, B1) slightly longer than antenna 1; peduncular articles 3-5 with length ratio of $1.0: 2.7: 1.7$; flagellum with 14 articles, articles $1-5$ each with calceolus anteriorly. Upper lip (Fig. 3C), anterior surface with 2 long thick setae in middle and several long setae sublaterally, ventral margin with many short thin setae. Mandibles (Fig. 3D, D1, E, E1) with left and right incisors bearing 4 cusps; left lacinia mobilis 4 -toothed and right one bifid, left accessory blades 4 in number and right ones 3; article length ratio of palp 1.0:3.0-3.1:3.5, articles 1 and 2 bare, article 3 with long proximolateral seta, 2 penicillate setae at mid-length on medial margin, and 3 long and 1 penicillate distal setae, ventral surface pubescent. Lower lip (Fig. 3F) with short mandibular process, apical part of outer lobe setose, apical part of inner lobe with sparse setae. Maxilla 1 (Fig. 3G, G1) with ovoid inner plate bearing single long plumose seta; outer plate bearing 11 dentate robust setae apically; tip of palp article 2 with 1 thick and several slender setae. Maxilla 2 (Fig. $3 \mathrm{H}$ ) with both plates setose apically, medial margin of inner plate bearing single seta. Maxilliped (Fig. 3I) with inner plate bearing several distal setae and many dorsal thin setae; outer plate large, medial to distal margin setose; palp stout, articles 1-3 wide, article 4 narrow, claw-shaped, distal end of article 2 not exceeding outer plate, medial margins of articles 1-3 and distal margin of article 3 setose.

Pereon. Gnathopod 1 (Fig. 4A) with coxa expanded distally, bearing 4 setae on ventral margin; basis with 2 anterior and 1 posterior long setae; merus with bifid seta and several thin setae on posterior margin; carpus posterodistal lobe with 3 distal and 1 medial setae, lateral surface covered with thin setae; propodus about 1.4 times as long as carpus, anterodistal corner with several long setae, palm weakly setose, without robust setae, anteromedial surface covered with thin setae; dactylus slender. Gnathopod 2 (Fig. $4 \mathrm{~B}, \mathrm{~B} 1$ ) with coxa narrowed distally, bearing single ventral seta; basis with posterodistal short seta; carpus with 2 bifid setae and many thin setae on posterior margin; propodus about 2.05 times as long as carpus, palm slightly concave posteromedially, with 5 posteromedial and 4 medial robust setae; dactylus slender, almost reaching proximal-most robust seta. Pereopods 3 and 4 (Fig. 4C, D) slender, longer than gnathopod 2; coxae subquadrate, each with 3 ventral setae; bases bearing 1-2 posterior setae; anterodistal corners of meri and carpi setose; dactyli long, about 0.65-0.7 times of propodi. Pereopod 5 (Fig. 4E, E1), coxa bearing anterior 


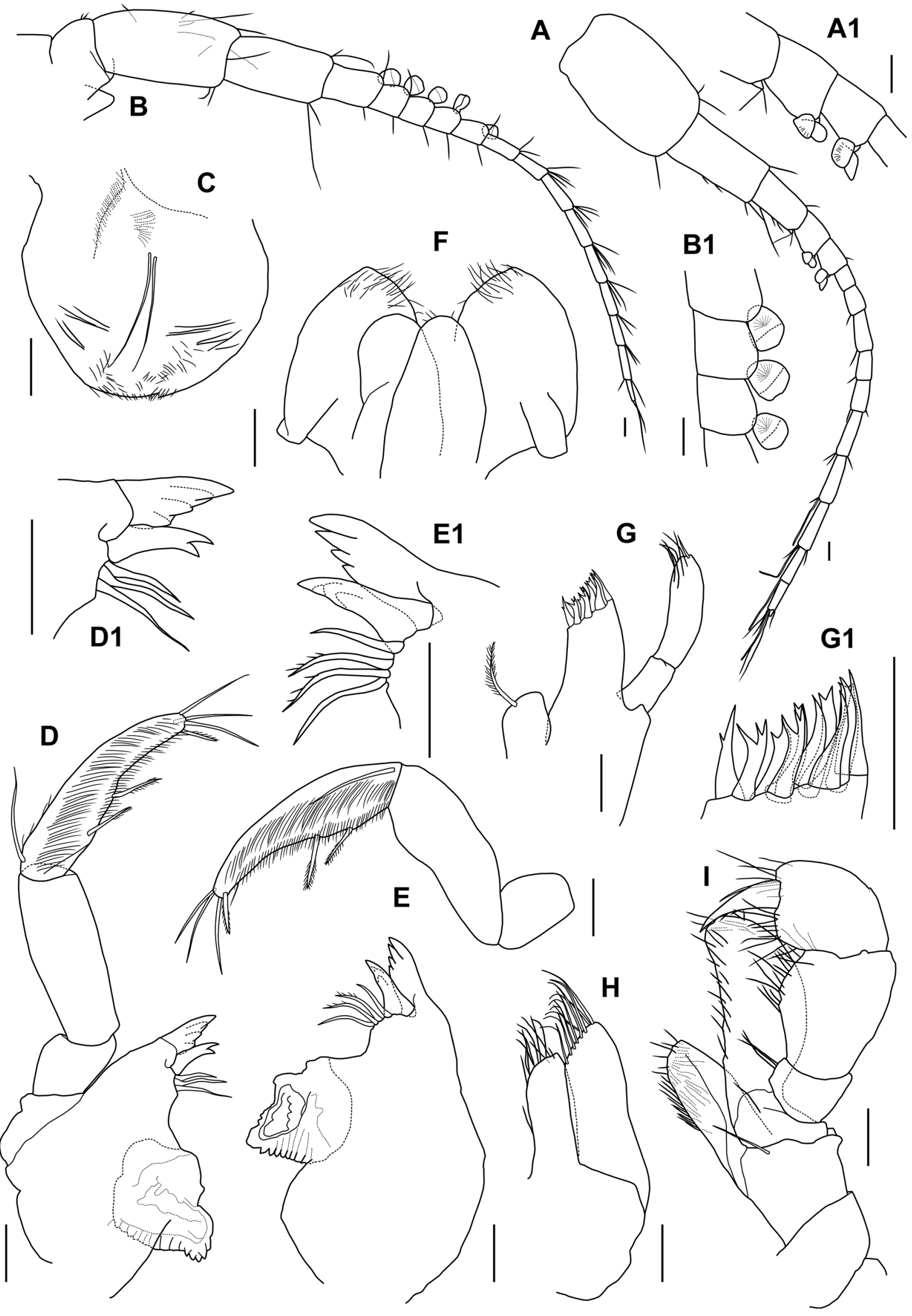


and posterior lobes of same depth, posterior lobe with 1 robust and 1 short setae; basis with many anterior setae, posteromedial surface bearing long plumose seta; merus with 3 anterior and 4 anterodistal setae, posterior margin bearing 2 plumose and 2 simple setae, posterodistal corner with 3 setae; carpus with 2 anterior short robust setae, anterodistal and posterodistal corners setose; propodus with anterodistal robust seta; dactylus long, about 0.6 times of propodus. Pereopod 6 (Fig. 4F) longer than pereopod 5; posterior lobe of coxa deeper than anterior lobe, with 1 robust and 1 short setae; basis with 4 anterior and 4 posteromedial long plumose setae; merus with 4 setae on anterior margin, posterior margin bearing 4 long plumose setae and 2 simple setae, anterodistal and posterodistal corners setose; carpus with 2 anterior setae, anterodistal and posterodistal corners setose; propodus with 3 anterior short robust setae; dactylus long, about 0.55 times of propodus. Pereopod 7 (Fig. 4G) $>1.35$ times as long as pereopod 6; coxa subrectangular, broader than long, with 2 short setae posteroventrally, gill absent; basis wide, anterior margin with 4 short robust setae, posterior margin minutely serrate, with 3 long plumose setae distomedially; ischium with 2 robust setae at anterodistal corner; merus with $1+2$ robust setae on anterior margin and $2+1$ robust setae on posterior margin, anterodistal and posterodistal corners setose; carpus with $1+2$ robust setae on anterior margin and $1+1$ robust setae on posterior margin, anterodistal and posterodistal corners setose; propodus with $1+3$ robust setae on anterior margin and $1+1$ robust setae on posterior margin, anterodistal and posterodistal corners setose; dactylus straight, with 2 posterior short setae, tip lost.

Pleon. Pleonal epimera (Fig. 5A), ventral margins of epimera 1 and 2 bearing 1 and 2 robust setae, respectively. Pleopods 1 and 2 (Fig. 5B, C) similar in length, pleopod 3 (Fig. 5D) shorter; peduncles each with 2 coupling hooks, peduncle of pleopod 1 with 2 lateral and 1 medial plumose setae; outer rami slightly shorter than inner rami, with 10 articles, inner rami bearing 9-10 articles. Uropod 1 (Fig. 5E) with peduncle bearing 6 dorsolateral and 2 dorsomedial robust setae; outer and inner rami about 1.05 and 1.3 times as long as peduncle, respectively, each with 2 robust setae. Uropod 2 (Fig. 5F) with peduncle bearing robust seta on dorsolateral margin; outer and inner rami about 1.3 and 1.6 times as long as peduncle, respectively, each with 3 robust setae. Uropod 3 (Fig. 5G) with peduncle bearing mediodistal robust seta; outer and inner rami about 1.5 and 1.7 times as long as peduncle, with 1 and 2 robust setae, respectively. Telson (Fig. $5 \mathrm{H}$ ) longish oval, with 2 minute setae subdistally.

Description of female [based on paratype (OMNHAr-12081, $2.3 \mathrm{~mm}$ )]. Body (Fig. 6) more inflated than that of male. Eyes smaller than those of male (diameter: $5.4 \%$ of
BL). Antenna 1 (Fig. 7A, A1), peduncular articles 1-3 with length ratio of 1.0:0.7:0.5, article 1 stout; accessory flagellum 1-articuate, with 2 setae on tip; flagellum with 9 articles, articles 5 and 7-9 each bearing aesthetasc at distal end. Antenna 2 (Fig. 7B, B1) slightly shorter than antenna 1 ; peduncular articles $3-5$ with length ratio of $1.0: 2.5: 2.25$; flagellum with 10 articles.

Gnathopod 1 (Fig. 7C) with ovoid coxa, ventral margin with 4 setae; basis anterior margin and posterodistal corner with 2 long and 1 middle-sized setae, respectively; merus with slender seta and several thin setae on posterior margin; carpus posterodistal lobe with 3 distal and 2 medial setae, lateral surface covered with thin setae; propodus about 1.2 times as long as carpus, palm weakly setose, without robust setae, anterolateral and anteromedial surfaces covered with thin setae. Gnathopod 2 (Fig. 7D) slightly larger than gnathopod 1; coxa subrectangular, with 3 setae ventrally, oostegite large, oval; basis with 2 short setae anteriorly, posterior margin and posterodistal corner bearing 1 and 2 setae, respectively; merus with 2 slender and several thin setae on posterior margin; carpus with posterodistal lobe twice as long as broad, posterior margin lined with thin setae, apical margin with several setae; propodus about 1.4 times as long as carpus, lacking robust setae on palm. Oostegites on coxae 3 and 4 (Fig. 7E, F) very wide and narrow, respectively. Pereopod 5 (Fig. 7G) with coxa bearing narrow oostegite; basis anterior margin with 2 plumose and several simple setae, posteromedial surface without plumose seta (lost?); merus with 2 anterior and 3 anterodistal setae, posterior margin bearing single plumose and 2 simple setae, posterodistal corner with 4 setae; carpus short, propodus long, dactylus curved. Pereopod 7 (Fig. 7H) with coxa narrowed ventrally, bearing small gill; basis wide, anterior margin with 4 short robust setae, posterior margin minutely serrate, with 2 medial long plumose setae; ischium-propodus almost same as those of male; dactylus about 1.1 times as long as propodus, straight.

Variation. Small male (OMNH-Ar-12083, $2.1 \mathrm{~mm})$. Gnathopod 2 (Fig. 7I) almost same as that of holotype (OMNHAr-12077, $2.8 \mathrm{~mm}$ ), but propodus less dilated, palm with 4 posteromedial and 4 medial robust setae. Females (OMNHAr-12078-12080, 2.5, 2.4, 2.3 mm, respectively). Pereopod 5 coxa, posteromedial surface with a plumose seta.

Coloration of specimen shortly after fixation (Fig. 8). Eyes reddish black; posterior margins of pereonites, pleonites and urosomite 1 dark red; other body and appendages pale red with sparse red spots.

Remarks. This new species is very similar to M. shimantoensis. A closer re-examination of the type specimen of $M$. shimantoensis revealed several new characters not described originally, which indicate similarity as well as difference be-

Fig. 3. Mucrocalliope ryukyuensis sp. nov., A-F, H, I, holotype, male (OMNH-Ar-12077), $2.8 \mathrm{~mm}$; G, paratype, male (OMNH-Ar-12078), $2.5 \mathrm{~mm}$. A, Right antenna 1, ventrolateral view; A1, accessory flagellum and calceoli on right antenna 1, ventrolateral view; B, right antenna 2, lateral view; B1, calceoli on flagellar articles 1-3 of right antenna 2, lateral view; C, upper lip, anterior view; D, right mandible, ventral view; D1, incisor, lacinia mobilis and accessory blades of right mandible, ventral view; E, left mandible, ventral view; E1, incisor, lacinia mobilis and accessory blades of left mandible, ventral view; F, lower lip, ventral view; G, right maxilla 1, dorsal view; G1, distal part of outer plate of right maxilla 1, dorsal view; $\mathrm{H}$, right maxilla 2, dorsal view; I, left maxilliped, ventral view. Scales: $0.03 \mathrm{~mm}$. 

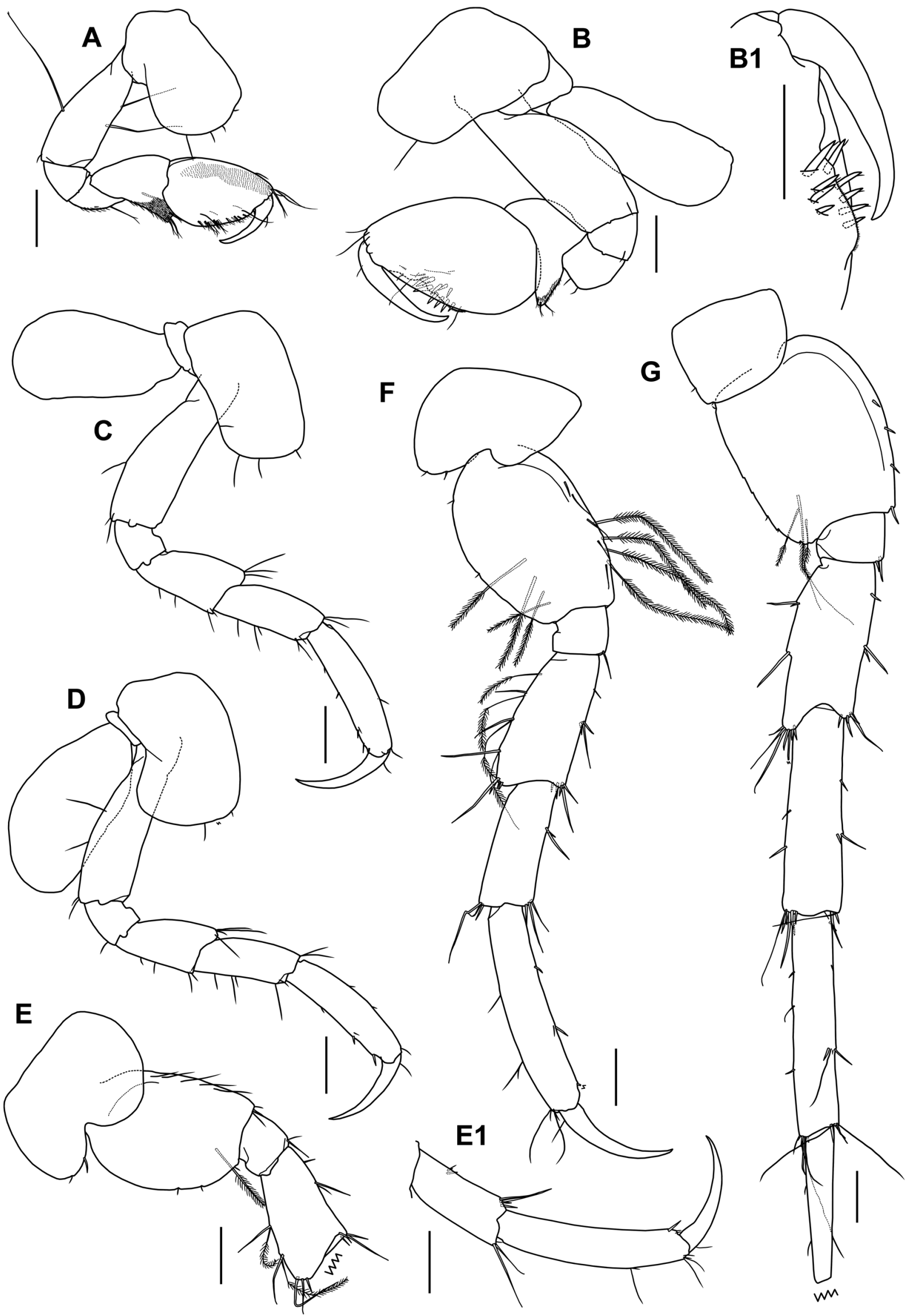

Fig. 4. Mucrocalliope ryukyuensis sp. nov., A-G, holotype, male (OMNH-Ar-12077), $2.8 \mathrm{~mm}$; E1, paratype, male (OMNH-Ar-12078), $2.5 \mathrm{~mm}$. A, Right gnathopod 1, lateral view; B, left gnathopod 2, lateral view; B1, palm and dactylus of left gnathopod 2, medial view, slender setae omitted; C-G, right pereopods 3-7, lateral views, gills on coxae 5, 6 lost; E1, carpus-dactylus of left pereopod 5 (reversed). Scales: $0.1 \mathrm{~mm}$. 

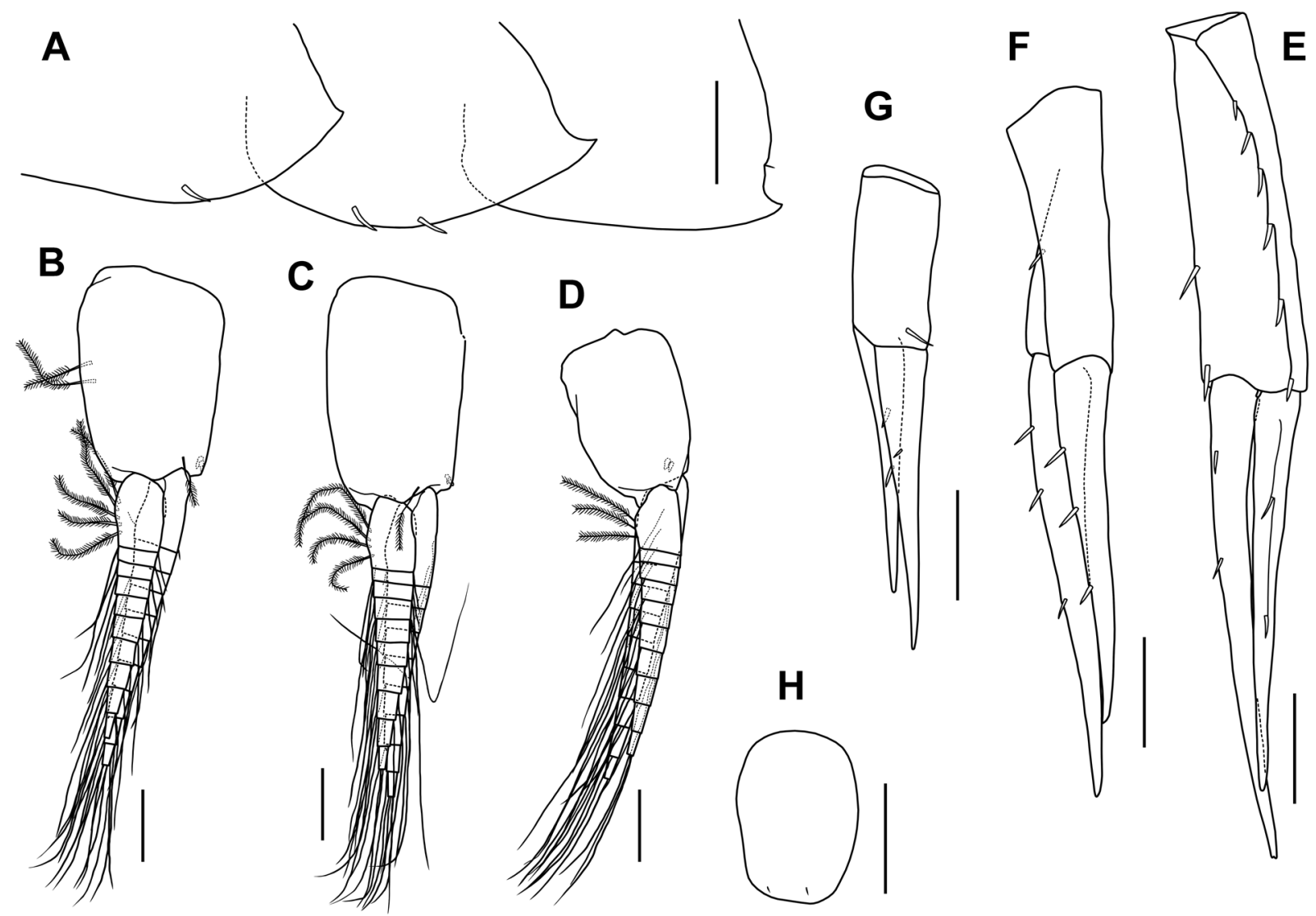

Fig. 5. Mucrocalliope ryukyuensis sp. nov., holotype, male (OMNH-Ar-12077), $2.8 \mathrm{~mm}$. A, Left epimeral plates 1-3, lateral view; B-D, right pleopods 1-3, anterior views; E, right uropod 1, dorsolateral view; F, right uropod 2, lateral view; G, left uropod 3, medial view; $H$, telson, dorsal view. Scales: $0.1 \mathrm{~mm}$.

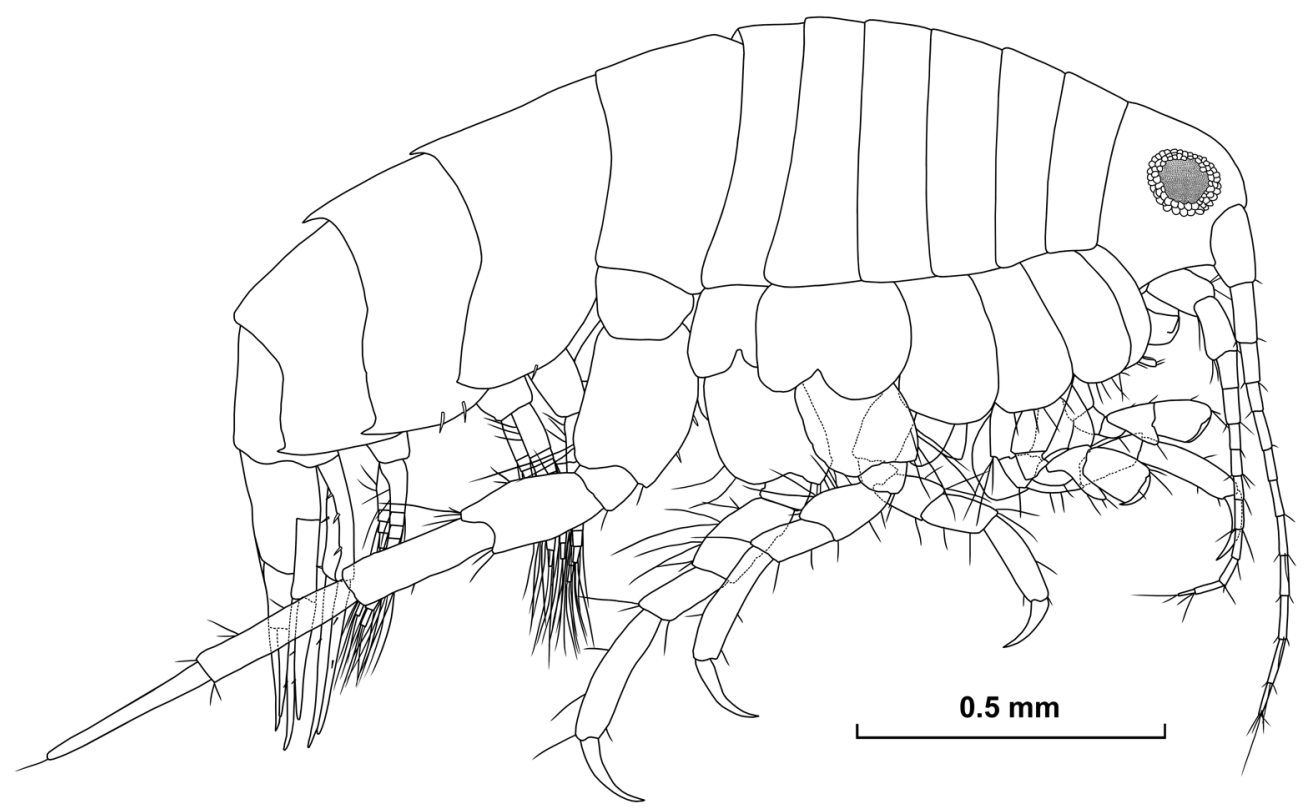

Fig. 6. Mucrocalliope ryukyuensis sp. nov., paratype, ovigerous female (OMNH-Ar-12081), $2.3 \mathrm{~mm}$, habitus, right lateral view.

tween the two species. Both species share the upper lip with long setae and the female pereopod 7 with coxal gill. However, $M$. ryukyuensis sp. nov. has the male antenna 2 with larger length ratio of 5 th peduncular article to 4 th article (Fig. 9) and the basis of male pereopod 5 with a posterome- dial plumose seta, which is lacking in M. shimantoensis. In addition, amphipod fauna in the Ryukyu Archipelago mostly differs from that in the other parts of Japan (e.g., Ariyama 2020) and habitat of the species is different from that of $M$. shimantoensis (estuary located $1.8 \mathrm{~km}$ upstream from river 


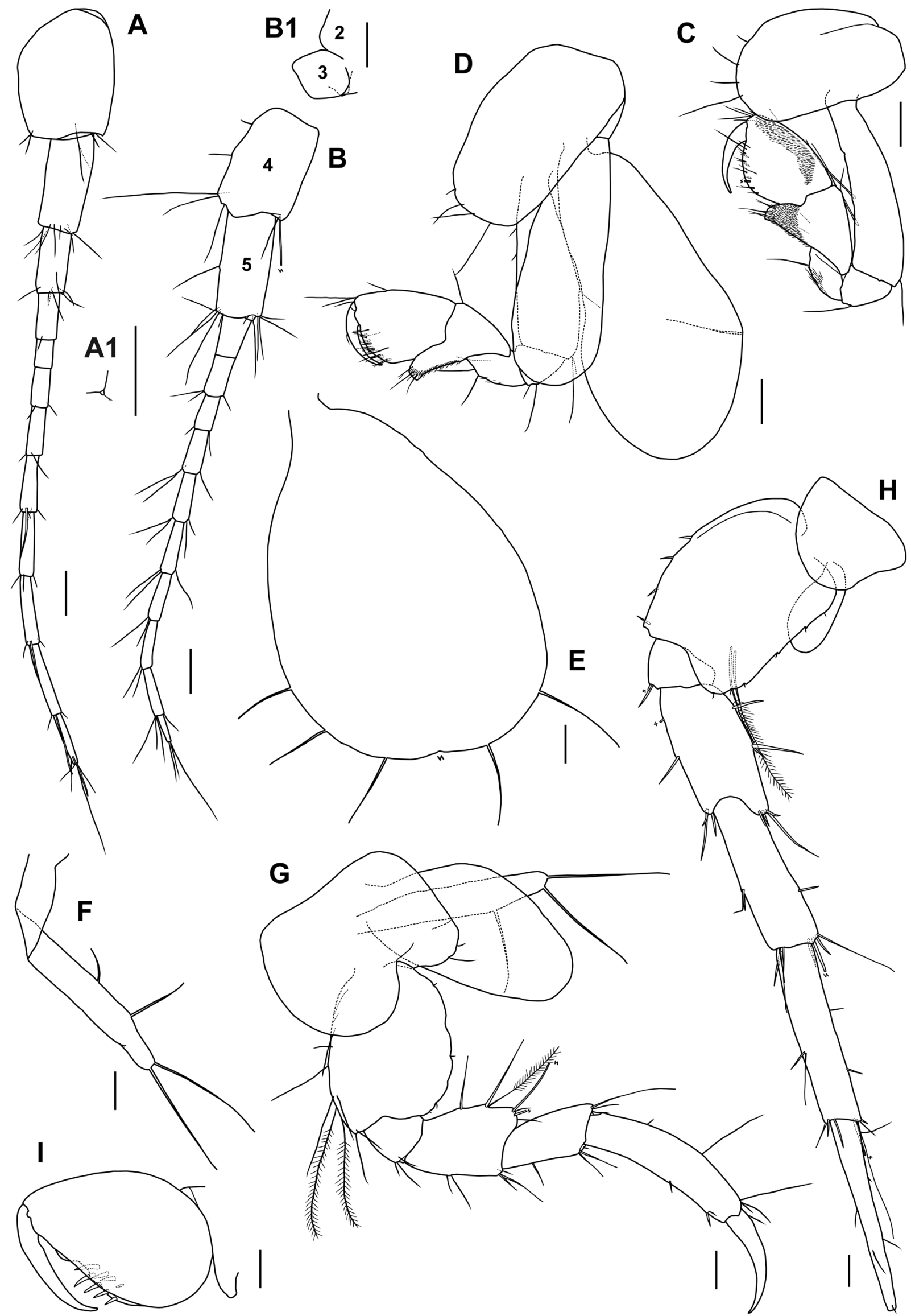

Fig. 7. Mucrocalliope ryukyuensis sp. nov., A-H, paratype, ovigerous female (OMNH-Ar-12081), $2.3 \mathrm{~mm}$; I, paratype, male (OMNHAr-12083), $2.1 \mathrm{~mm}$. A, B, Left antennae 1, 2, lateral views; A1, accessory flagellum of left antenna 1, lateral view; B1, peduncular articles 2, 3 of right antenna 2, lateral view (reversed); C, D, left gnathopods 1, 2, lateral views; E, F, oostegites on left coxae 3, 4, lateral views; G, H, left pereopods 5, 7, lateral views; I, propodus and dactylus of left gnathopod 2, lateral view, slender setae omitted. Scales: $0.05 \mathrm{~mm}$. 


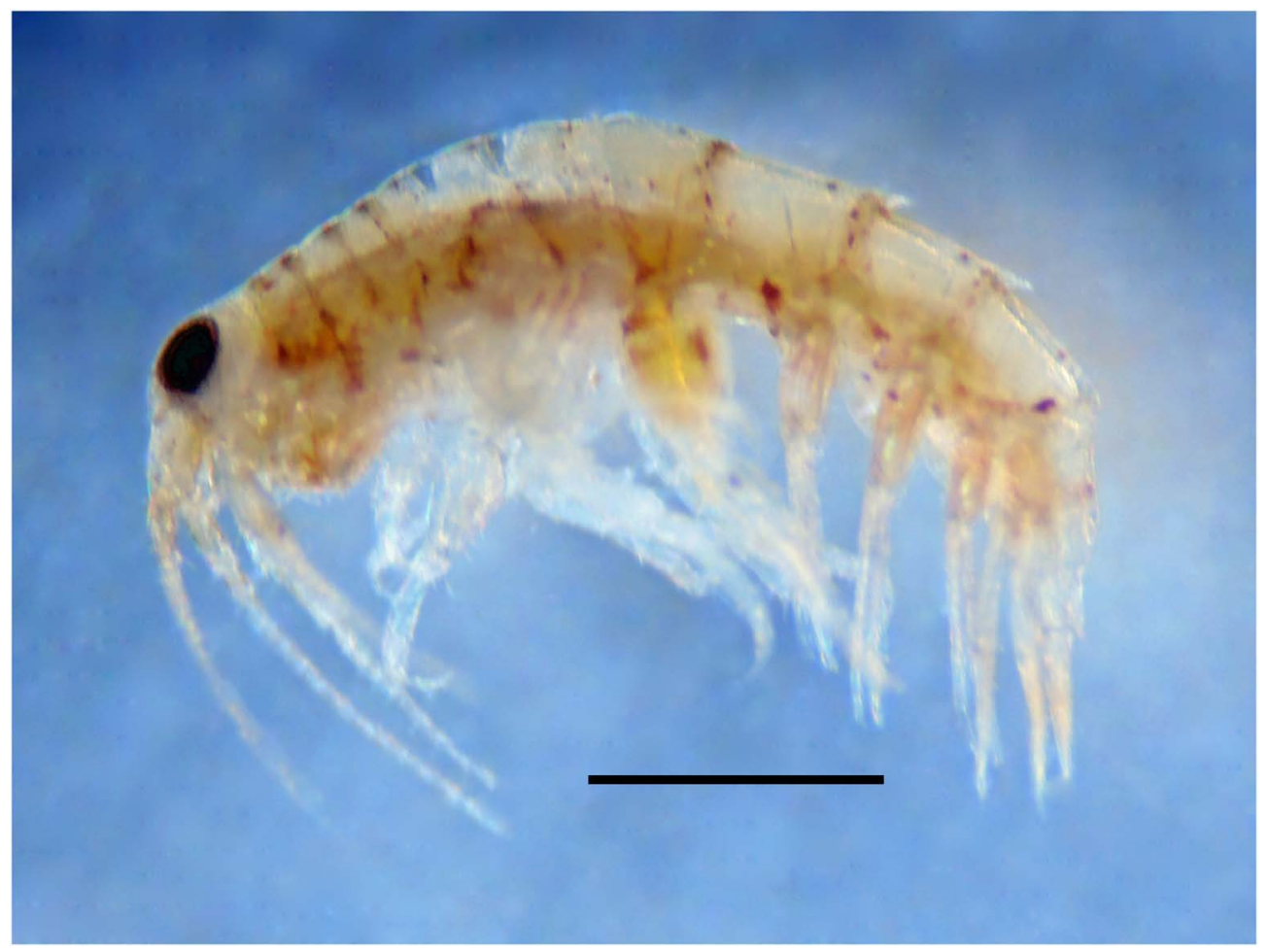

Fig. 8. Mucrocalliope ryukyuensis sp. nov. Photograph of a fixed specimen (male, 7 hours after fixation) collected together with paratype female (OMNH-Ar-12082), $2.3 \mathrm{~mm}$, most part of pereopod 7 lost. Scale: $0.5 \mathrm{~mm}$.

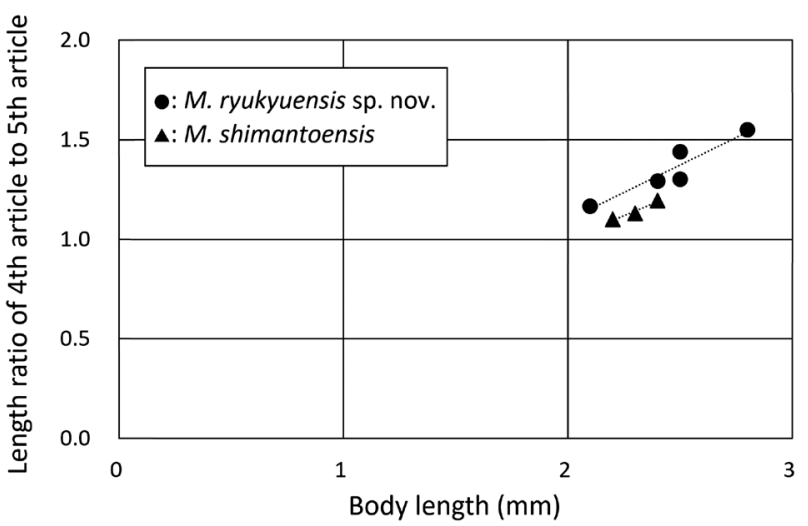

Fig. 9. Mucrocalliope ryukyuensis sp. nov. and M. shimantoensis Ariyama and Azuma, 2011. Length ratio of 4th article to 5th article in male antenna 2 peduncle relative to body length.

mouth); therefore, M. ryukyuensis is assumed to be an independent species in spite of small differences.

Habitat. Intertidal and uppermost subtidal, sandy or mud bottom, brackish.

Distribution. Japan: Kakeroma Island in Kagoshima Prefecture and Okinawa and Iriomote Islands in Okinawa Prefecture (present study).

Genus Paracalliope Stebbing, 1899

[Japanese name: Genkotsu-yokoebi-zoku]

Paracalliope Stebbing, 1899: 210; Barnard 1972: 70; Barnard and Karaman 1982: 181; Barnard and Karaman 1991: 571;
Barnard and Drummond 1992: 2.

Paroediceropsis Fearn-Wannan, 1968: 50.

Type species. Calliope fluviatilis Thomson, 1879, fixed by original designation.

Diagnosis. Body subcylindrical, posterodorsal margins of pleonites 1 and 2 smooth, urosomites 2 and 3 coalesced. Rostrum short; eyes large or medium-sized, clearly separated; antennal sinus shallow. Antennae slender, male antennae usually with calceoli; antenna 1 peduncular article 3 shorter than article 1, accessory flagellum vestigial. Mandibular palp present; incisor and molar developed. Maxilla 1 with inner plate strongly setose medially; outer plate with many apical robust setae; palp 2-articulated, with apical setae. Maxilla 2 with both plates bearing apical setae, inner plate with dense medial setae. Maxillipedal palp consisting of 4 articles, exceeding outer plate. Coxae strongly overlapping; coxae 1-4 longer than broad, 5-7 short, coxae 5 and 6 bilobed; gills present on coxae 2-6 in both sexes; oostegites of female present on coxae $2-5$, oostegites on coxae 2 and 3 large. Gnathopod 1 of both sexes small, subchelate; carpus with posterodistal lobe. Male gnathopod 2 stout, subchelate; carpus short, with narrow posterodistal lobe; propodus dilated, palm oblique, with several robust setae. Female gnathopod 2 small, subchelate; carpus with posterodistal lobe. Pereopods 3-6 not fossorial. Pereopods 3 and 4 similar; bases slender; dactyli curved. Pereopods 5 and 6 each with expanded basis and curved dactylus. Pereopod 7 extremely long; basis expanded; dactylus elongate, tapering distally. Pleonal epimera each with posteroventral tooth. Uropods biramous, slender; inner rami longer than outer rami. Telson entire, longer 


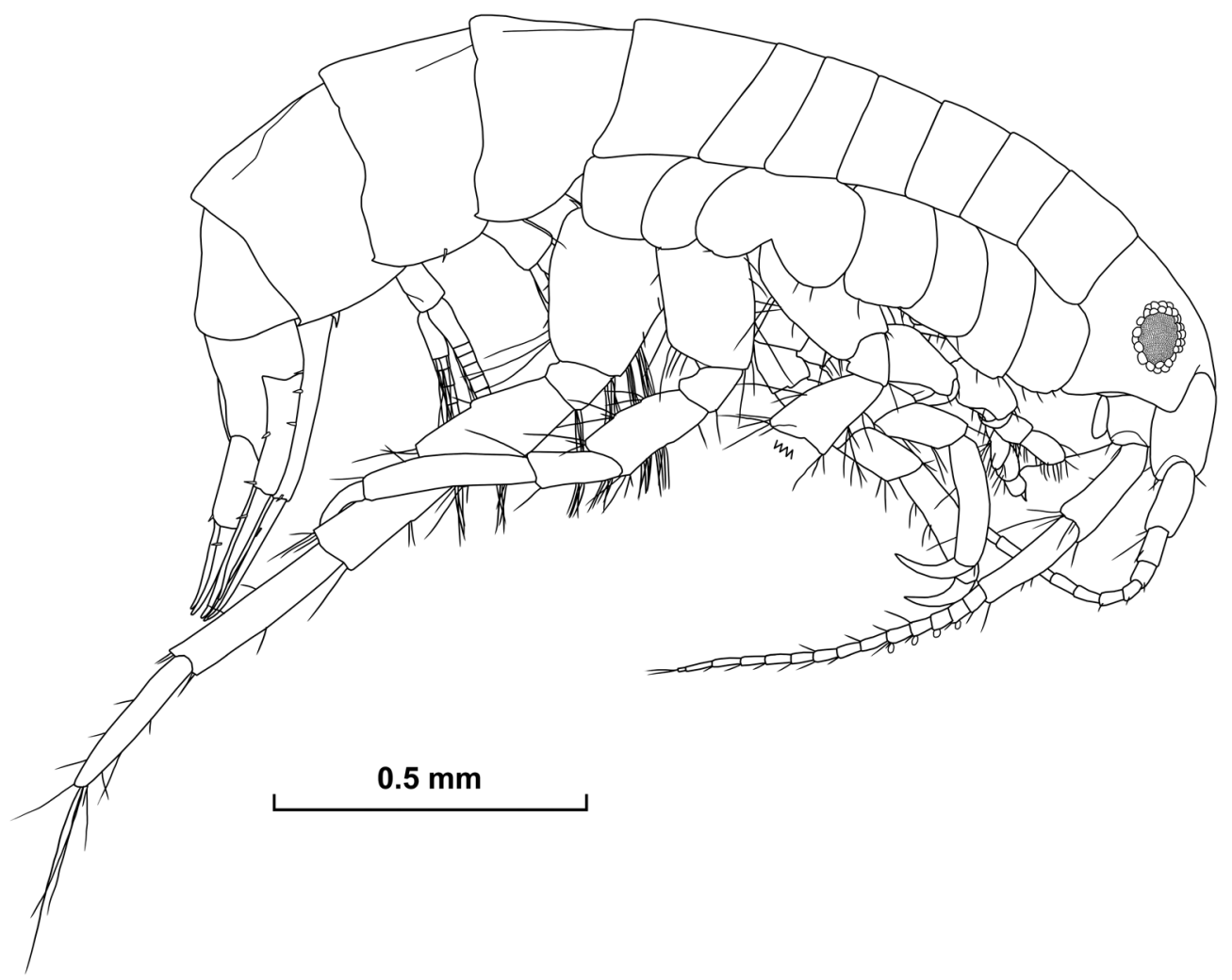

Fig. 10. Paracalliope dichotomus Morino, 1991, male (OMNH-Ar-12087), $2.3 \mathrm{~mm}$, habitus, right lateral view.

than broad.

Included species. Twelve species: P. australis (Haswell, 1880); P. bacescui Ortiz and Lalana, 1997; P. dichotomus; $P$. fluviatilis (Thomson, 1879); P. karitane Barnard, 1972; P. larai Knott, 1975; P. lowryi Barnard and Drummond, 1992; P. mapela Myers, 1985; P. novacaledoniae Ruffo and Paiotta, 1972; P. novizealandiae (Dana, 1852); P. raymondi (FearnWannan, 1968); P. vicinus Barnard and Drummond, 1992.

Remarks. Paracalliope can be distinguished from Mucrocalliope by the absence of the dorsal teeth on the pleonites and the medially setose inner plates of the maxillae.

Paracalliope dichotomus Morino, 1991

[Japanese name: Shiokawa-yokoebi]

(Figs 10-12)

Paracalliope dichotomus Morino, 1991: 20, figs 6-8; Aoyagi 2011: 109, fig. 1.

Material examined. Four males (OMNH-Ar-1208512088), 2.5, 2.4, 2.3 and $2.1 \mathrm{~mm}$, respectively, 3 ovigerous females (OMNH-Ar-12089-12091), 1.9, 1.8 and $1.7 \mathrm{~mm}$, respectively, and 1 ovigerous female (OMNH-Ar-12180, not dissected), $1.8 \mathrm{~mm}$, Sashiki, Okinawa Island, Okinawa
Prefecture, $26^{\circ} 10^{\prime} 31^{\prime \prime} \mathrm{N}, 127^{\circ} 47^{\prime} 29^{\prime \prime} \mathrm{E}$ (Fig. 1C), middle intertidal, sandy mud bottom in stream, 4 July 2015, coll. H. Ariyama.

Description of male (based on OMNH-Ar-12087, $2.3 \mathrm{~mm}$ ). Body (Fig. 10) relatively slender; head with medium-sized eyes (diameter: $5.2 \%$ of $\mathrm{BL}$ ); pereonite 1 mediumsized, pereonites 2-6 narrow, pereonite 7 and pleonites 1-3 wide. Antenna 1 (Fig. 11A, A1), peduncular articles 3-5 with length ratio of 1.0:0.7:0.3, article 1 stout; accessory flagellum 1-articulate, with 2 setae on tip; flagellum with 12 articles, last article small, articles 1-4 each with calceolus medially, articles 7, 9-11 each with aesthetasc at distal end. Antenna 2 (Fig. 11B) slightly longer than antenna 1; peduncular articles 3-5 with length ratio of $1.0: 2.65: 2.5$; flagellum with 14 articles, last article small, articles $2-5$ each with calceolus anteriorly. Gnathopod 1 (Fig. 11C, C1) with oval coxa, bearing 3 setae on ventral margin; basis bare; merus with 2 setae and many thin setae on posterior margin; carpus posterodistal lobe with 4 bifid setae distally and many thin setae on lateral surface; propodus about 1.3 times as long as carpus, anterodistal corner with 2 thick setae, palm oblique, weakly setose, without robust setae; dactylus slender, minutely bifurcate apically. Gnathopod 2 (Fig. 11D, D1), coxa longish ovoid, bearing 3 ventral setae; basis with

Fig. 11. Paracalliope dichotomus Morino, 1991, A-D, male (OMNH-Ar-12087), $2.3 \mathrm{~mm}$; E, ovigerous female (OMNH-Ar-12180), $1.8 \mathrm{~mm}$; F-I, ovigerous female (OMNH-Ar-12090), $1.8 \mathrm{~mm}$. A, F, Right antenna 1, lateral views; A1, F1, accessory flagellum of right antenna 1, medial views; $\mathrm{B}, \mathrm{G}$, right antenna 2, lateral views; $\mathrm{C}, \mathrm{H}$, right gnathopod 1, lateral views; $\mathrm{C} 1$, palm and dactylus of right gnathopod 1, lateral view, slender setae omitted; D, I. right gnathopod 2, lateral views; D1, palm and dactylus of right gnathopod 2, lateral view, slender setae omitted; E, head, right lateral view. Scales: $0.05 \mathrm{~mm}$. 


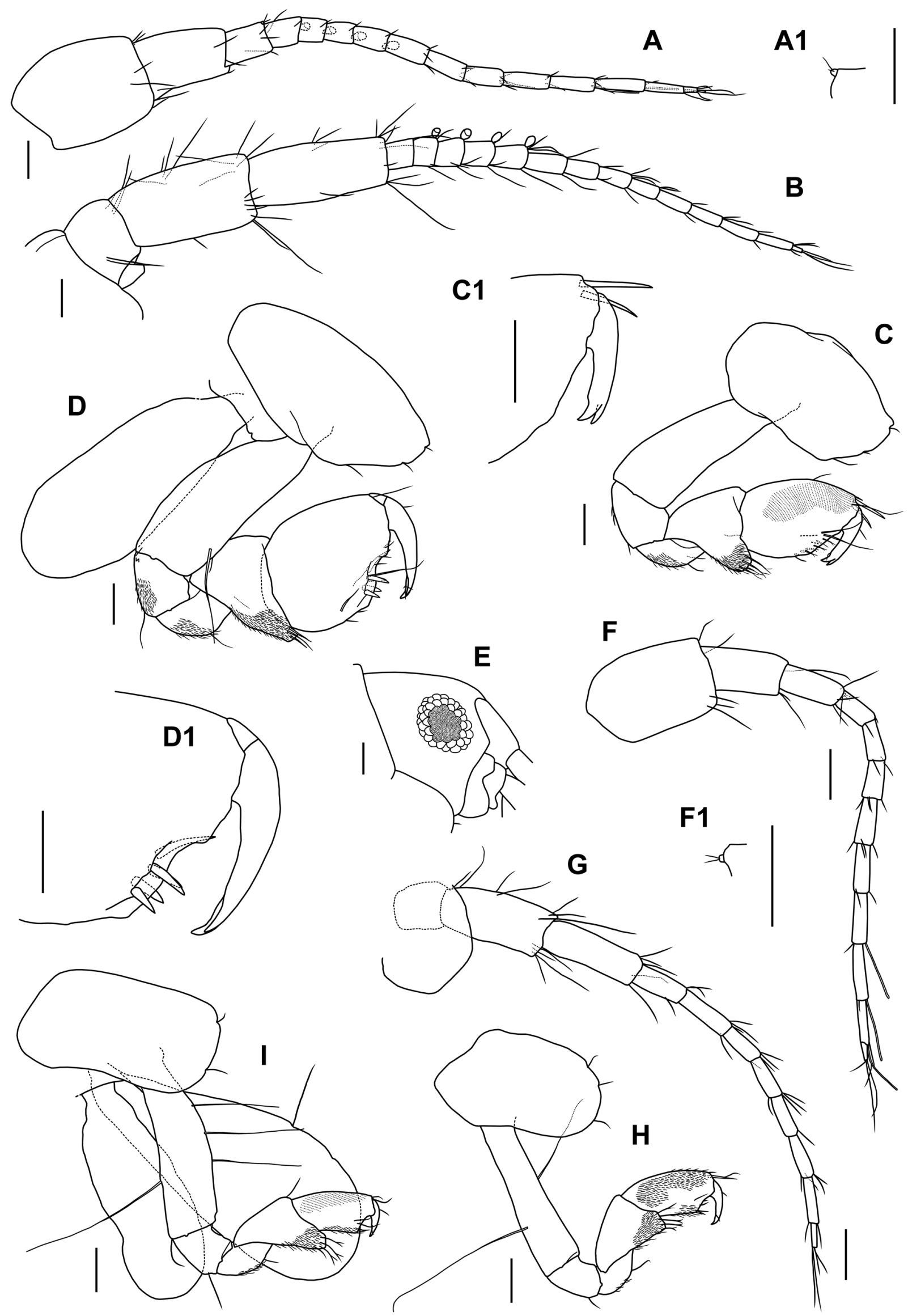




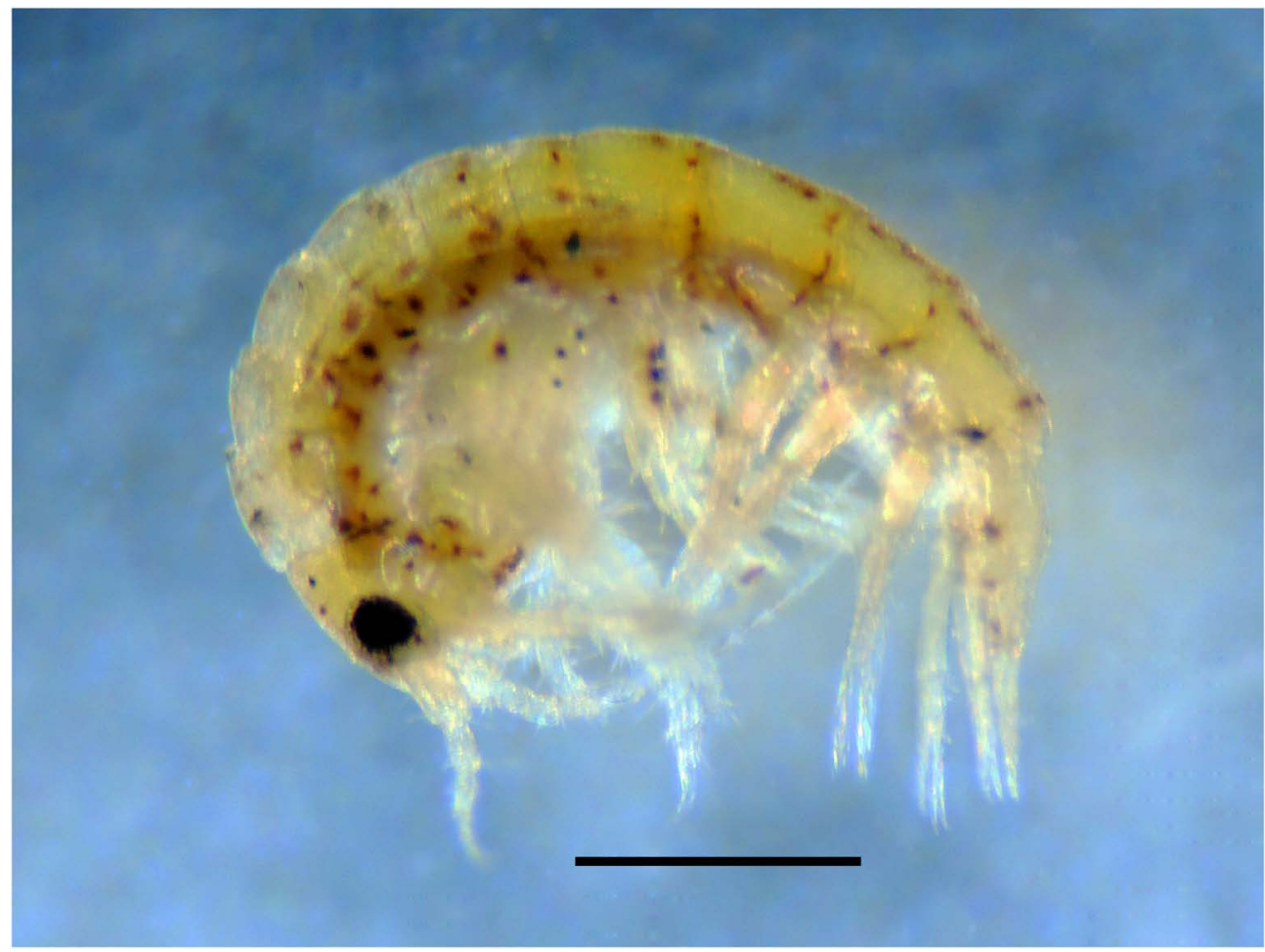

Fig. 12. Paracalliope dichotomus Morino, 1991. Photograph of a fixed specimen (male, 3.5 hours after fixation) collected together with examined specimens (OMNH-Ar-12085-12091), most part of pereopod 7 lost. Scale: $0.5 \mathrm{~mm}$.

single anterior long seta; ischium and merus each with slender seta and many lateral thin setae posteriorly; carpus posterodistal lobe with 4 distal and 5 medial setae and many thin setae on lateral surface; propodus about 1.8 times as long as carpus, palm slightly concave posterolaterally, with 2 posterolateral and 3 medial robust setae; dactylus slender, almost reaching end of palm, bifurcate apically.

Description of female (based on OMNH-Ar-12090, $1.8 \mathrm{~mm}$, and OMNH-Ar-12180, $1.8 \mathrm{~mm}$ only for head). Body more inflated than that of male. Head (Fig. 11E) smaller than that of male, with medium-sized eyes (diameter: $5.5 \%$ of $\mathrm{BL}$ ). Antenna 1 (Fig. 11F, F1), peduncular articles $1-3$ with length ratio of $1.0: 0.65: 0.5$, article 1 stout; accessory flagellum 1-articulate, tip with 2 setae; flagellum with 9 articles, last article small, articles 6-8 each with aesthetasc at distal end. Antenna 2 (Fig. 11G) slightly shorter than antenna 1; peduncular articles 3-5 with length ratio of $1.0: 2.0: 1.85$; flagellum with 8 articles, last article small. Gnathopod 1 (Fig. 11H) with oval coxa, bearing 3 setae on ventral margin; basis slender, with 1 anterior and 1 posterior long setae; merus bearing single seta and several thin setae on posterior margin; carpus posterodistal lobe with 4 bifid setae distally and many thin setae on lateral surface; propodus narrow, about 1.25 times as long as carpus, anterodistal corner with single thick seta, palm weakly oblique, without robust setae, posterolateral and anteromedial surfaces and posterior margin covered with thin setae; dactylus slender, not bifurcate. Gnathopod 2 (Fig. 11I) slightly larger than gnathopod 1; coxa subrectangular, bearing 2 ventral setae; basis with 3 anterior and 1 posterior long setae; merus bearing single seta and several thin setae on posterior margin; carpus posterodistal lobe with 4 bifid setae distally and many thin setae on lateral surface; propodus narrow, about 1.1 times as long as carpus, palm weakly oblique, lacking robust setae, anteromedial surface and posterior margin covered with thin setae; dactylus slender, not bifurcate.

Coloration of specimen shortly after fixation (Fig. 12). Eyes dark brown; posterior margins of pereonite 7, pleonites 1 and 2 dark red; other body and appendages pale orange with irregular dark red spots.

Remarks. Morphological characters of the male specimens almost agree with the original description and figures (Morino 1991). But there are trifle differences; these specimens have (1) head with shallower antennal sinus, (2) wider peduncular article 1 of antenna 1, and (3) gnathopod 2 basis lacking long seta on posterior margin. The bifurcate dactyli of the male gnathopods 1 and 2 are distinctive to the genus. The morphology in female and the coloration are firstly clarified in the present study.

Habitat. Middle intertidal, sandy mud bottom in stream (present study); salty spring (Morino 1991); waterway and small river near coast (Aoyagi 2011).

Distribution. Japan: Okinawa Island (Morino 1991; present study) and Iheya and Izena Islands (Aoyagi 2011) in Okinawa Prefecture.

Paracalliope dichotomus is designated as a near-threatened (NT) species (Okinawa Prefecture 2017; Ministry of the Environment, Government of Japan 2020); in my survey, this species was not collected from the other islands (Amami-ōshima, Kakeroma and Iriomote Islands). 


\section{Acknowledgements}

I express my sincere thanks to Dr. Ryohei Yamanishi of Nishinomiya Shell Museum and Dr. So Ishida of OMNH who provided equipment for observation. I am also grateful to two anonymous reviewers and Dr. Naoya Ohtsuchi of the University of Tokyo for appropriate comments on the manuscript. This study was supported in part by a grant from the Fujiwara Natural History Public Interest Incorporated Foundation.

\section{References}

Aoyagi, M. 2011. A new record of Paracalliope dichotomus (Amphipoda Paracalliopiidae) from Iheyajima and Izenajima islands, Ryukyu Islands, Japan. The Biological Magazine Okinawa 49: 109-112. [In Japanese]

Ariyama, H. 2016. Two new species of eyeless amphipods from a coastal area in Japan (Crustacea: Amphipoda: Hadziidae, Melitidae), with reinstatement of the genus Paraniphargus Tattersall, 1925. Journal of Natural History 50: 2277-2297.

Ariyama, H. 2020. Six species of Grandidierella collected from the Ryukyu Archipelago in Japan, with descriptions of four new species (Crustacea: Amphipoda: Aoridae). Zootaxa 4810: 1-44.

Ariyama, H. and Azuma, K. 2011. A new genus and species of Paracalliopiidae (Crustacea: Amphipoda) from the Shimanto estuary, western Japan. Species Diversity 16: 137-147.

Ariyama, H. and Moritaki, T. 2020. A new species of the genus Bathyc- eradocus from the Kumano-nada, central Japan (Crustacea: Amphipoda: Maeridae). Crustacean Research 49: 61-71.

Barnard, J. L. 1972. The marine fauna of New Zealand: algae-living littoral Gammaridea (Crustacea Amphipoda). Memoir of the New Zealand Oceanographic Institute 62: 7-216.

Barnard, J. L. and Drummond, M. M. 1992. Paracalliope, a genus of Australian shorelines (Crustacea: Amphipoda: Paracalliopiidae). Memoirs of the Museum of Victoria 53: 1-29.

Barnard, J. L. and Karaman, G. S. 1982. Classificatory revisions in gammaridean Amphipoda (Crustacea), part 2. Proceedings of the Biological Society of Washington 95: 167-182.

Barnard, J. L. and Karaman, G. S. 1991. The families and genera of marine gammaridean Amphipoda (except marine gammaroids). Part 2. Records of the Australian Museum, Supplement 13: 419-866.

Fearn-Wannan, H. J. 1968. Littoral Amphipoda of Victoria. Part 1. Proceedings of the Royal Society of Victoria 81: 31-58.

Ministry of the Environment, Government of Japan. 2020. Ministry of the Environment Red List 2020. Available at https://www.env. go.jp/press/files/jp/114457.pdf (19 October 2020). [In Japanese]

Morino, H. 1991. Gammaridean amphipods (Crustacea) from brackish waters of Okinawa Island. Publications of Itako Hydrobiological Station 5: 13-26.

Okinawa Prefecture. 2017. Threatened Wildlife in Okinawa, Third Edition (Animals) - Red Data Okinawa-. Available at https://www. pref.okinawa.jp/site/kankyo/shizen/hogo/okinawa_rdb_doubutu. html (19 October 2020). [In Japanese]

Stebbing, T. R. R. 1899. Revision of Amphipoda (continued). Annals and Magazine of Natural History, 7th Series 4: 205-211.

Steel, D. H. and Steel, V. J. 1991. The structure and organization of the gills of gammaridean Amphipoda. Journal of Natural History 25: 1247-1258. 